Available online at GSC Online Press Directory

GSC Biological and Pharmaceutical Sciences

e-ISSN: 2581-3250, CODEN (USA): GBPSC2

Journal homepage: https://www.gsconlinepress.com/journals/gscbps

(RESEARCH ARTICLE)

\title{
Study of consuming habits of people of Prayagraj towards their health and taste
}

\author{
Mishra Yogesh * \\ Department of Zoology Bhawan's Mehta P.G. College Bharwari Kaushambi Uttar Pradesh, India. \\ Publication history: Received on 05 April 2020; revised on 18 April 2020; accepted on 20 April 2020
}

Article DOI: https://doi.org/10.30574/gscbps.2020.11.1.0086

\begin{abstract}
Over the last few years restaurants, cafes and international fast food outlets have proliferated in India and eating out has become popular particularly among younger consumers. The online food ordering business is still growing and it is experiencing exponential growth and several online delivery companies are emerging and becoming successful. Are these foods which we consume safe? The question always arises in mind. Yes it is always safe whatever the food it may be, for example a street food. The food which is made in our houses, the food which we order in a restaurant or hotels, they are always useful but the question arises how? The answer to this is to eat food only understanding your requirement. If you eat the food more, may it be highly nutritious; it is surely going to damage you. Yet many of us continue to consume more calories than we need. It is so that people don't know how many calories they need to eat each day. The reason behind this is overeating habit they learn from their families. So what is the thing which we are so thrive of feeding it more, yes it is the taste, the taste for correction. The tendency of most Indian people is increasing towards taste conscious not health conscious. Let us take India, more than $90 \%$ of population is taste conscious not health conscious. This leads to malnutrition and disfunctioning of daily routine. It has become hazardous situation for Indians. If not controlled it would lead to so many fatal results. The survey of the study was done at different places of Naini region and Prayagraj city in Prayagraj. The study population consisted of 67 people of different age group. The aim of the study is to contribute better strategic and technical marketing decisions. The findings of this study are important for government bodies interested in designing public health programs.
\end{abstract}

Keywords: Fast food; Street food; Taste/health conscious; Malnutrition; Hazardous

\section{Introduction}

Rapid changes in diets and lifestyles that have occurred with industrialization, urbanization and economic development have accelerated over the past century. This is having a significant impact on the health and nutritional status of population. While standards of living have improved, food availability has expanded and become more diversified. There have also been significant nugatory outcomes in terms of inappropriate dietary patterns and decreased physical activities and a corresponding increase in diet-related chronic (WHO/FAO expert consultation, 2003). With the increasing awareness of people about their health, the concept of health consciousness has gained importance. Health consciousness defines the readiness to undertake health actions (Becker, Maiman, Kirscht, Haefner and Drachman, 1977).The food when it is tasty mesmerizes us and need for that becomes greater. It is something which our taste buds are fond of. It's good to eat tasty food but what in front of taste, you have forgotten limit of how much to eat. This is the point where you are followed by a bad habit. Health conscious consumers are aware and concerned about their wellness and are motivated to improve their health, quality of life and being self-conscious regarding health. These individuals tend to be aware of nutrition and physical fitness (Michaelidou and Hassan (2008). The foods which we eat are burgers, pizza's, taco's, noodles, dosa, freties, French-fries, tandoor etc. Off course they are healthy no doubt and the rumor goes on that these are fast food we should not consume these kind of food (Kaushik JS, Narang M, Parikh A 2011). This is something we are interpreting our thoughts as wrong and just say that homemade foods are healthy. The correction

\footnotetext{
${ }^{*}$ Corresponding author: Mishra Yogesh
}

Copyright (C) 2020 Author(s) retain the copyright of this article. This article is published under the terms of the Creative Commons Attribution Liscense 4.0. 
here is homemade foods are made from hygienic practices but not in every house. This is what it makes it more healthy and trustworthy too. If we take an example of a chapati and a pizza, people would say the chapati is more nutritious, but in realty the pizza has more nutritious value. Both have composition made of carbohydrates, proteins, fats, vitamins and minerals. Pizza would have more nutritive values of these proportions than a chapati. The United States government states that the average man needs $2700 \mathrm{kcal}$ per day and average woman needs $2200 \mathrm{kcal}$ per day. Not everybody needs the same number of calories each day. Starting a day routine of a normal person, he needs to have breakfast, lunch and something to eat at evening and dinner. Assume a person A has to eat chapatti in breakfast, lunch, at evening and at the time of dinner and another person B having a pizza 4 times a day. Suppose a person would require $350 \mathrm{kcal}-400 \mathrm{kcal}$ of energy per day for doing his work normally. Now let's see the composition of pizza would be always more calories than a chapati; around 2.5 times greater. Let us compare the nutrient content of pizza and chapati (table-1).

Table 1 Comparison of nutrient content of pizza and chapati

\begin{tabular}{lll}
\hline Food components & Pizza & chapati \\
\hline Carbohydrate & $50 \mathrm{gm}$. & $20 \mathrm{gm}$. \\
Fats & $50 \mathrm{gm}$. & $20 \mathrm{gm}$. \\
Vitamins & $50 \mathrm{gm}$. & $20 \mathrm{gm}$. \\
Minerals & $50 \mathrm{gm}$. & $20 \mathrm{gm}$. \\
protein & $50 \mathrm{gm}$. & $20 \mathrm{gm}$. \\
\hline
\end{tabular}

Let us calculate how much energy he gets when he consumes each for 4 times a day (table-2).

Table 2 Comparison of energy consumption of pizza and chapati in a day

\begin{tabular}{lll}
\hline Food components & Pizza & chapati \\
\hline Carbohydrate & $200 \mathrm{kcal}$ & $80 \mathrm{kcal}$ \\
Fats & $200 \mathrm{kcal}$ & $80 \mathrm{kcal}$ \\
Vitamins & $200 \mathrm{kcal}$ & $80 \mathrm{kcal}$ \\
Minerals & $200 \mathrm{kcal}$ & $80 \mathrm{kcal}$ \\
protein & $200 \mathrm{kcal}$ & $80 \mathrm{kcal}$ \\
\hline
\end{tabular}

The total energy acquired by the person A is $1000 \mathrm{kcal}$ which is 2.5 times greater than the required energy and it is going to affect the health of person A. The total energy acquired by the person B is $400 \mathrm{kcal}$ which is enough for a normal person. The calculations were made taking into account the accepted 2000 Kilocalorie that a healthy person requires in a day. There are some food standard issued to public by World Health Organisation, National Institute of Nutrition India, ICMR and the scientific expert group of the Food Safety and Standards Authority of India. The Recommended Dietary Allowance (RDA) for salt was reached at $5 \mathrm{gm}$, fat $60 \mathrm{gm}$. and carbohydrate $300 \mathrm{gm}$. for one person in a day. The trans-fat limit was 2.2g. (A report of WHO, NIN, ICMR and FSSAI (2019).

\section{Material and Methods}

Marketing theories state that customer's satisfaction and loyalty depends on quality, price and other factors. Enterprises should evaluate price impact on customer's loyalty. When the price of a good or product changed, customers may judge again buying that product or goods (Dovaline, Virvilaite, Saladiene, and Skindaras, 2009). Price flexibility can affect customers purchase decisions and as a result loyalty too. A set of question were asked to different age group of people at a particular area. The study population consisted of 67 people of different caste and aged in three categories of below 20 years, 20-60 years and above 60 years living in different places of district Prayagraj Uttar Pradesh. Their attitudes were assessed using the health and taste consciousness. Dietary data was obtained using a food frequency questionnaire. The choice of people was random but in the same age group. The survey was done at different places of Prayagraj. The places selected for the study were Tagore town, Georgetown, Katra, Naini, Kharkauni, Maheva and some places of Gaughat.

The questions which were asked to different age groups were- 
Q 1. What would you prefer to eat a pizza or a glass of orange juice? (People, below 20 year). Out of 25 people 6 people chose orange juice for consumption and 19 people chose pizza. (Table -3)

Q 2. How many times can you have bottle gourd in your meal? (People, in the age group of 20-60 years). Out of 25 people only 15 chose for 1-3 days and other 7 chose every day and 3 never (table-3).

Q 3. What would you like to prefer a homemade food or at a restaurant? If restaurant then how many days in a week you would prefer restaurant food? (People above 60 years). Out of 17 people only 10 who chose homemade food and the rest 7 people chose restaurant food. (Table-3)

Table 3 Name of people surveyed and their food choice

\begin{tabular}{|c|c|c|c|c|c|}
\hline \multicolumn{2}{|c|}{ Below 20 years } & \multicolumn{2}{|c|}{ 20-60 years } & \multicolumn{2}{|c|}{ Above 60 years } \\
\hline Name & Food choice & Name & $\begin{array}{l}\text { Food } \\
\text { choice[Days] }\end{array}$ & Name & Food choice \\
\hline 1.Arpit & Pizza & Syrians & 1-3 Days & Dhirendra & Home made \\
\hline 2.Jacob & Pizza & Amit & 1-3 Days & Suyukti & Home made \\
\hline 3.Anukarsh & Pizza & Ms Rishi & 1-3 Days & Namrta & Home made \\
\hline 4.Varsha & Pizza & Harshit & 1-3 Days & Afroj & Home made \\
\hline 5.pooja & Pizza & Saumya & 1-3 Days & Mamta & Home made \\
\hline 6.Shubham & Pizza & Alok & 1-3 Days & Neelam & Home made \\
\hline 7.Ujjwala & Pizza & Jaya Prakash & 1-3 Days & Rajesh & Home made \\
\hline 8.Rakshit & Pizza & Arvind & 1-3 Days & Akash & Home made \\
\hline 9.Deeksha & Pizza & Dheeraj & 1-3 Days & Sohan & Home made \\
\hline 10.Jaya & Pizza & Avaneesh & 1-3 Days & Shivram & Home made \\
\hline 11.Kirti & Pizza & R.C. Mishra & 1-3 Days & Satish & Restaurant \\
\hline 12.Anushka & Pizza & Aman & 1-3 Days & Prakash & Restaurant \\
\hline 13.Kartikey & Pizza & Ashutosh & 1-3 Days & Sheetal & Restaurant \\
\hline 14.Rahul & Pizza & V.N. Shukla & 1-3 Days & Ashish & Restaurant \\
\hline 15.Deepak & Pizza & Manoj & 1-3 Days & Puneet & Restaurant \\
\hline 16.Vaibhav & Pizza & Ramanand & Everyday & Mudit & Restaurant \\
\hline 17.Anupam & Pizza & Rohit & Everyday & Vivek & Restaurant \\
\hline 18.Abhinav & Pizza & Ratan & Everyday & - & - \\
\hline 19.Harpreet & Pizza & Utkarsh & Everyday & - & - \\
\hline 20.Aditi & Orange Juice & Vijay & Everyday & - & - \\
\hline 21.Ravi & Orange Juice & Shipra & Everyday & - & - \\
\hline 22.Suman & Orange Juice & Rajeev & Everyday & - & - \\
\hline 23.Ashish & Orange Juice & Aslam & Never & - & - \\
\hline 24.Anshuman & Orange Juice & Asif & Never & - & - \\
\hline 25.Shivam & Orange Juice & Saif & Never & - & - \\
\hline
\end{tabular}

\section{Results and discussion}

From the early ages, our behavior towards food seems to be heavily influenced by their taste and flavor. This predisposition tends to remain with us throughout life as we see from adult food desires that are characterized by sweet 
taste and redolence (Clark and Wood, 1998). According to Kearney J. Kearney, Dunne and Gibney (2000), the most important factor perceived by adults to affect food choice is: Freshness. The study shows that people who choose orange juice were health conscious and the one who choose pizza were taste conscious. A question was also asked to these people who were below 20 years of age that why you choose orange juice and why not pizza the answer was that orange juice is tasty than pizza. It shows that the one who preferred orange juice, unaware of its health benefits. So According to survey all people who were below 20 years of age were taste conscious and the percentage of taste conscious people below 20 year of age is 100\% ( Sahoo K, Sahoo B, Chaudhary AK, Sofi NY, Kumar R, Bhadoriya AS et. al., 2015) (table-4). For age group above20 years and below 60 years the people who chose to eat bottle gourd for 1-3 days in a weak they knew about the benefits and damaging effect to body, were health conscious. The people who were unaware of the consequences of overeating bottle gourd were considered taste conscious. The people who have answered every day, were asked why? The answer was because it is tasty to them. The people who said never, considered as taste conscious because when asked why, they said that they don't like. The percentage of taste conscious of such people between 2060 years of age was $60 \%$ and the health conscious $40 \%$ (table-4). The people who were above the age of 60 years were more likely homemade food but only little tastes conscious because they felt that home food was tasty than the restaurant food. The percentage of being taste conscious people of above 60 years of age was $59 \%$ and health conscious $41 \%$ (table-5). Out of 67 people surveyed the result was $73 \%$ taste conscious and $27 \%$ health conscious (Table-5). The problem here is not being the food is unhealthy and healthy. The problem lies within habit of eating or how much of food is being consumed. If even a chapati is consumed much it is going to harm our body. The example of pizza and chapati says everything. If we ate a pizza in the morning it is sufficient for our whole day diet but we consume some other foods just for the sake of our taste buds. A report by the Indian Council of Medical Research (ICMR, 2016) shows a worrying trend. A disease burden occurred due to unhealthy diet, high blood pressure, high cholesterol and overweight has increased from 10 to 25 per cent since 1990 to the end of 2019.

Table 4 Percentage of taste conscious people

\begin{tabular}{llll}
\hline & Age Group & Taste conscious \% & Health conscious \% \\
\hline A & Below age 20 years & $100 \%$ & 0 \\
B & Between age 20-60 years & $60 \%$ & $40 \%$ \\
C & Age above 60 years & $59 \%$ & $41 \%$ \\
\hline
\end{tabular}

Table 5 Total Percentage of taste conscious people

\begin{tabular}{ll}
\hline Total Number of people surveyed & Taste conscious \% \\
\hline 67 & $73 \%$ \\
\hline
\end{tabular}

\section{Conclusion}

It is good to eat tasty food which is not bad for health but up to a limit. Consuming more than the required dose it affects health of a human body. A food which is tasty doesn't mean that it is noodles, pizza, burger or any other street food commonly termed as fast foods. It is something a person likes a particular food more in quantity. It changes from person to person i.e. at the same place people find a burger as tasty and a person loves to have bottle gourd every time. Consuming bottle gourd each and every day may cause dis-balance in acid and base composition of the human body. It is clear that a person would consume the food more at a time if the food is tasty to him and It is very harmful to human health. Over-eating is a habit which is to be controlled. Because of overeating and the intake of these foods it causes release of neurotransmitter, and decrease in levels of serotonin, as a result it causes depression and anxiety. A lab study by the Centre for Science and Environment (CSE) in December 2019 found extremely high level of salt, fat and trans fat in junk foods responsible for obesity and non-communicable diseases like hypertension, diabetes and heart ailments. To eat food its good but the result here are of over eating. Do know what foods we are consuming, do check the nutrition table of the packet food. Make your diet in a proper manner. Do consume outdoor foods but in a limited sense. The aim of the study is to contribute better strategic and marketing decisions important for public / private sector bodies in designing public health programs. 


\section{Compliance with ethical standards}

\section{Acknowledgments}

The author expresses his gratitude to Prof. Sangeeta Srivastava former Head (Home Science) Allahabad Central University and presently as a Vice-chancellor of Prof. Rajendra Singh (Rajju Bhaiya) University Prayagraj for their intellectual inputs and sophisticated guidance for carrying out the research work. I am very thankful to Mr. Mayank Mishra, a B. Tech. student in food technology SHUATS, Naini Prayagraj for their help throughout the study period.

\section{Disclosure of conflict of interest}

The author declares that there is no conflict of interest.

\section{Statement of informed consent}

Informed consent was obtained from all individual participants included in the study.

\section{References}

[1] WJ and FE. (2003). Diet, Nutrition and prevention of Chronic Diseases. World Health Organ. Tech Rep Ser, 916.

[2] Becker MH, Maiman LA, Kirscht JP, Haefner DP and Drachman RH. (1977).The Health Belief Model and Prediction of Dietary Compliance. A Field Experiment Journal of Health and Social Behavior, 18, 348-366.

[3] Michaelidou N and Hassan LM. (2008).The Role of Health Consciousness, Food Safety Concern and Ethical Identity on Attitudes and Intentions towards Organic Food. International Journal of Consumer Studies, 32(2), 163-170.

[4] Kaushik JS, Narang M and Parikh A. (2011). Fast food consumption in children. Indian pediatric, 48, 97-101.

[5] A report of Indian council of medical Research .Nutritive value of Indian foods. National institute of Nutrition, Hyderabad, India. (2019). Junk Food, Down To Earth, 25-30.

[6] Virvilaite R, Saldine V and Skindaras D. (2009). The Relationship between Price and Loyalty in Services Industry. Engineering Economics, 63(4), 96-104.

[7] Dovaliene A and Virvilaite R. (2008). Customer Value and its Contribution to the Longevity of Relationship with service provider: The Case of Theatre Industry Engineering Economics, 1(56), 66-73.

[8] Clark MA and Wood RC. (1998). Consumer Loyalty in the Restaurant Industry, a Preliminary Exploration of the Issues. International Journal of Contemporary Hospitality Management, 10(4), 139-144.

[9] Kearney M, Kearney JM, Dune A and Gibney MJ. (2000). Food in a Nationally Representative Sample of Irish Adults. Public Health Nutrition, 3(02), 219-226.

[10] Sahoo K, Sahoo B, Chaudhary AK, Sofi NY, Kumar R, Bhadoriya AS et.al (2015). Childhood obesity: causes and consequences, J Family Med prim care, 4, 187-92.

\section{How to cite this article}

Mishra Y. (2020). Study of consuming habits of people of Prayagraj towards their health and taste. GSC Biological and Pharmaceutical Sciences, 11(1), 180-184. 